\title{
Sarraceniopus nipponensis sp. nov. and S. hughesi (Astigmata, Histiostomatidae) from Sarraceniaceous Pitchers Bred in Japan
}

\author{
Kazumi TAgAMI* \\ Laboratory of Environmental Health, Division of Health and Sport Sciences, Graduate School of \\ Human comprehensive Science, University of Tsukuba, Tsukuba, Ibaraki 305-8574, Japan
}

(Received 5 October 2004; Accepted 17 November 2004)

\begin{abstract}
Insectivorous pitcher plants have long been favored by many Japanese hobbyists. Some species of the family Sarraceniaceae, endemic to northern America, have been artificially hybridized for a considerable period in Japan. Three species of the genus Sarraceniopus (Histiostomatidae) have been recorded from the cylindrical or tube-like leaves containing dead and decomposing insects in the U.S. and Canada. Leaves collected from the Kyoto University Experimental Farm (Kyoto Prefecture), Atagawa Tropical and Alligator Garden (Shizuoka Prefecture) and a flower shop in Tsukuba (Ibaraki Prefecture) were investigated for Sarraceniopus mites in Japan. As a result, two species of the genus were collected: Sarraceniopus hughesi (Hunter \& Hunter, 1964) was a new record in Japan and a new species, $S$. nipponensis sp. nov. is described here.
\end{abstract}

Key words: Pitcher plants, hybridization, Histiostomatidae, Sarraceniopus, Astigmata, exotic species

\section{INTRODUCTION}

The genus Sarraceniopus of the family Histiostomatidae consists of members recently transferred from the genus Anoetus. Members of this genus are known to inhabit Sarraceniaceae pitcher plants distributed in the temperate zone of North America (Fashing and OConnor, 1984), and three species of the genus-S. gibsoni (Nesbitt, 1954), S. hughesi (Hunter and Hunter, 1964) and S. darlingtoniae (Fashing and OConnor, 1984)- have been recorded from this area. In addition to Sarraceniopus, three other genera, Creutzeria (Oudemans, 1932), Nepenthacarus (Fashing, 2002), and Zwickia (Oudemans, 1924), have been recorded from tropical Nepenthaceae.

Despite the absence of indigenous Sarraceniaceae species in Japan, pitcher plants transplanted from North America grow well locally and are popular with Japanese enthusiasts. It is thus relatively easy to collect leaves of pitcher plants in Japan as some botanical gardens exhibit them, and they are widely sold as flowers or potted plants by flower shops and breeders. Since Japan is located far from the country of origin of the Sarraceniaceae, a variety of new influences (geographical, climatic, temporal, genetic and so on) currently act on pitcher plants and mites. The author studied pitcher mite fauna on cultured Sarraceni-

\footnotetext{
* Corresponding author: e-mail: tagk@taiiku.tsukuba.ac.jp
} 
aceae in Japan to compare with North American fauna, and described one new species and recorded one species of the genus Sarraceniopus from Japan.

\section{MATERIALS AND METHODS}

The Sarracenia specimens used for this study were donated by the Kyoto University Experimental Farm (Kyoto, western Japan), Atagawa Tropical and Alligator Garden (Atagawa, Higashi-Izu, Shizuoka Prefecture in south-central Japan) and a flower shop in Tsukuba (Ibaraki Prefecture in north-central Japan). The contents of the 20 fresh pitcher leaves that were sent to the laboratory were examined in this study. The plants could not be identified to the level of species given that most had been hybridized for several generations when first introduced to Japan.

Sufficient quantities of mites at different developmental stages (females, males and deutonymphs) were obtained from the pitcher plants. Identification to species level however, was not possible for the mites obtained from plant material from Atagawa and Tsukuba. The accumulation of decaying insects under conditions of moderate humidity in the pitcher environment is conducive to bacterial growth and provides a favorable environment for mites. A previously used method for rearing histiostomatid mites, a modification of a method used to rear acarid mites (Okabe and OConnor, 2001), was not appropriate for the mites collected from the pitchers in this study.

In this paper, nomenclature for idiosomal and leg setae followed Griffiths et al. (1990) and Grandjean (1939), respectively. The measurements of more than 117 morphological characters in males, 61 in deutonymphs, as well as an RLI index (ratio of length or distance of structure to idiosomal length, Kurosa, 2002) were examined in this study (Appendix).

Holotype and several paratype specimens will be deposited in the collection of the National Science Museum, Tokyo (NSMT). Other paratypes will be deposited in the National Museum of Natural History, Washington, D.C.

\section{DESCRIPTION AND RECORD}

\section{Genus Sarraceniopus Fashing and OConnor, 1984 Sarraceniopus nipponensis sp. nov.}

(Figs. 1-19)

FEMALE (Figs. 1-7). Body pear-shaped. Idiosomal length $432-536 \mu \mathrm{m}$, width 264 $376 \mu \mathrm{m}(\mathrm{n}=5)$.

Gnathosoma. Chelicerae (Fig. 1) owes fixed digit having a membranous finger-like distal portion and with 3 large well-developed teeth medially; movable digit with 50 teeth and a tiny apical seta; dorsal cheliceral seta as long as the movable digit. Apical palpal solenidion $(\omega)$ reflexed outward and medium length of 42-64 $\mu \mathrm{m}$. Eupathidial seta $\left(u l^{\prime}\right)$ short (less than $26 \mu \mathrm{m}$ ) and pointed inside (Fig. 3). Palpal membrane poorly developed. Ventral subcapitular seta $(m)$ filiform.

Dorsum (Fig. 2). Anterior propodosoma with a distinct sclerite extending posteriorly to a 


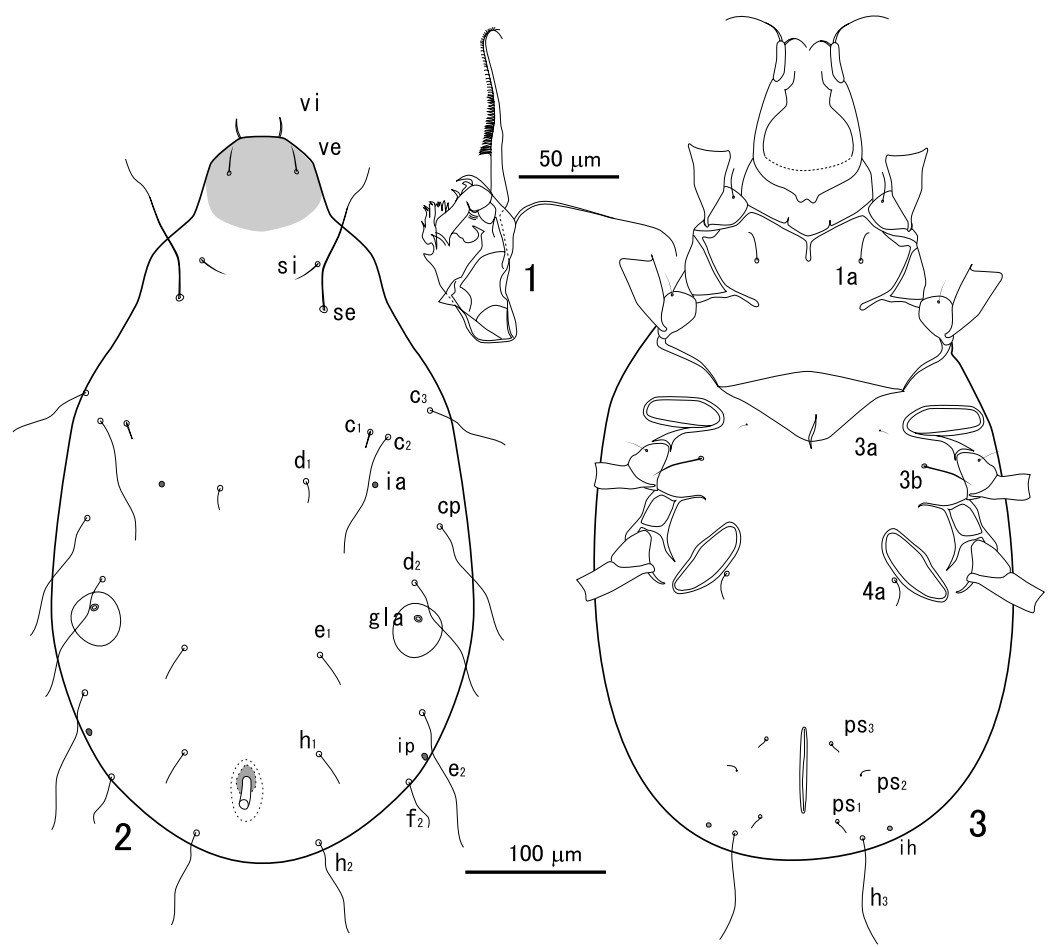

Figs. 1-3. Sarraceniopus nipponensis Tagami, sp. nov., female (holotype). 1, chelicera; 2, dorsum; 3 , venter. Scale bars are $50 \mu \mathrm{m}$ for 1 , and $100 \mu \mathrm{m}$ for 2 and 3.
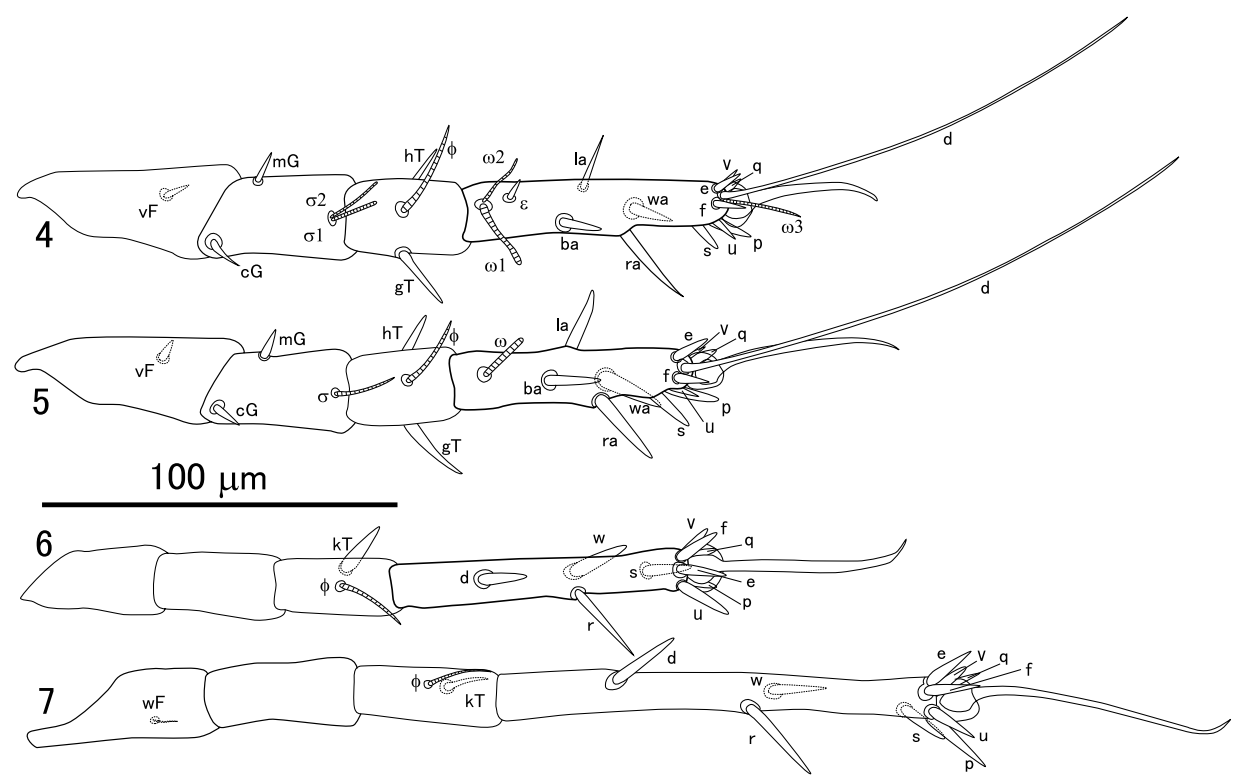

Figs. 4-7. Sarraceniopus nipponensis Tagami, sp. nov., female (holotype). 4, leg I; 5, leg II; 6, leg III; 7, leg IV. 
level anterior to leg I. Setae $v i$ and ve filiform. Scapular setae filiform; internal scapular seta (si) short, positioned antero-medial to external scapular seta (se); se longer than three times of $s i$. Sejugal furrow indistinct. Hysterosomal setae filiform, external setae $(c 2, c 3, c p, d 2$, $e 2, h 2, h 3)$ except $f 2$ longer than internal setae $(c l, d l, e l, h l)$. Oil gland $(g l a)$ is small. Two pairs of small cupules ( $\mathrm{i} a$ and $i p$ ) present, but im is invisible. Copulatory opening providing well-chitinized simple orifice with duct and bursa copulatrix.

Venter (Fig. 3). Anterior apodemes of coxa I fused medially to form Y-shape. Anterior and posterior papillae oval and well screlotized. Coxal setae short; $4 a$ located inside of the posterior papillae. Three pairs of short anal setae present. Cupules (ih) located lateral to seta $h 3$.

Legs (Figs. 4-7). Legs slender, with all five segments free. Chaetotaxy: tarsus 13-12-1010; tibia 2-2-1-1; genu 2-2-0-0; femur 1-1-0-1; trochanter 1-1-1-0. Solenidiotaxy: tarsi 3-1$0-0$; tibiae 1-1-1-1; genua 2-1-0-0. Famulus present. Tarsal solenidion $\omega 2$ present. Solenidion $\omega 3$ saber-like. Most setae spine-like except $w F$, which is filiform. Dorso-apical tarsal seta $d$ of tarsi I-II elongated, filiform; $d$ of tarsi III-IV spine shaped. Setae $p R$ of trochanter I and II, and $s R$ of trochanter III filiform.

MALE (Figs. 8-13). Body more rectangular than that of female, highly sclerotized; idiosomal length 300-392 $\mu \mathrm{m}$, width 204-224 $\mu \mathrm{m}$. Gnathosoma similar to that of female.

Dorsum (Fig. 8). Hysterosoma with a pair of sclerotized patches. Sejugal furrow visible. Hysterosomal setae as for female. Cupules $i a$ and im visible, but ip invisible. Opistosomal gland ( $g l a$ ) opening located between setae $d 2$ and $e 2$.

Venter (Fig. 9). Apodeme I like that of female. Apodeme II free. Posterior apodeme of leg II and anterior apodeme of leg III fused together, pointed inside and free medially. Anterior papillae oval and situated medially to apodeme IV and $3 b$; posterior papillae located antero-laterally to genital organ. Two pairs of anal setae ( $p s 1$ and $p s 2)$ present laterally to the anal slit, subequal length and filiform. Anal seta ps 3 absent. Hysterosomal seta $h 3(141-204 \mu \mathrm{m})$ longer than twice of $h 2$, located to the ventro-posterior margin.

Legs (Figs. 10-13). Tarsi of legs I-IV stouter and shorter than those of female. Chaetotaxy and solenidiotaxy of legs as in female. Solenidion $\sigma$ of leg II shorter $(13-15 \mu \mathrm{m})$ than that of female $(15-18 \mu \mathrm{m})$. Claws stouter and shorter than female. Claws of leg II longer than that of $S$. darlingtoniae and hooked.

DEUTONYMPH (Figs. 14-19). Body ovoid, widest at a level posterior to sejugal region; idiosomal length 194-260 $\mu \mathrm{m}$; width 136-172 $\mu \mathrm{m}(\mathrm{n}=6)$. Gnathosomal remnant of subcapitulum cylindrical, length $7-12 \mu \mathrm{m}$, width $8-10 \mu \mathrm{m}$. Palpal supracoxal seta ( $u l^{\prime}$ ) present on dorsolateral subapical region, its length $3 \mu \mathrm{m}$; distal portion of palpal solenidia slightly bifurcate, $29-34 \mu \mathrm{m}$ in length.

Dorsum (Fig. 14). Propodosoma triangular in shape, without transverse striation; setae $s c i$ and sce short. Hysterosoma with transverse striations anteriorly, and with smooth and simple surface; hysterosomal setae minute as propodosoma, except stouter $h 3$. Long oval cupule $i a$ present between $c 1$ and $c 2$; opistosomal gland present between $d 2$ and $e 2$; cupule ip invisible.

Venter (Fig. 15). Apodemes I fused together, located posterior to subcapitular remnant, and forming a long sternum which is free posteriorly; anterior apodemes II extending 


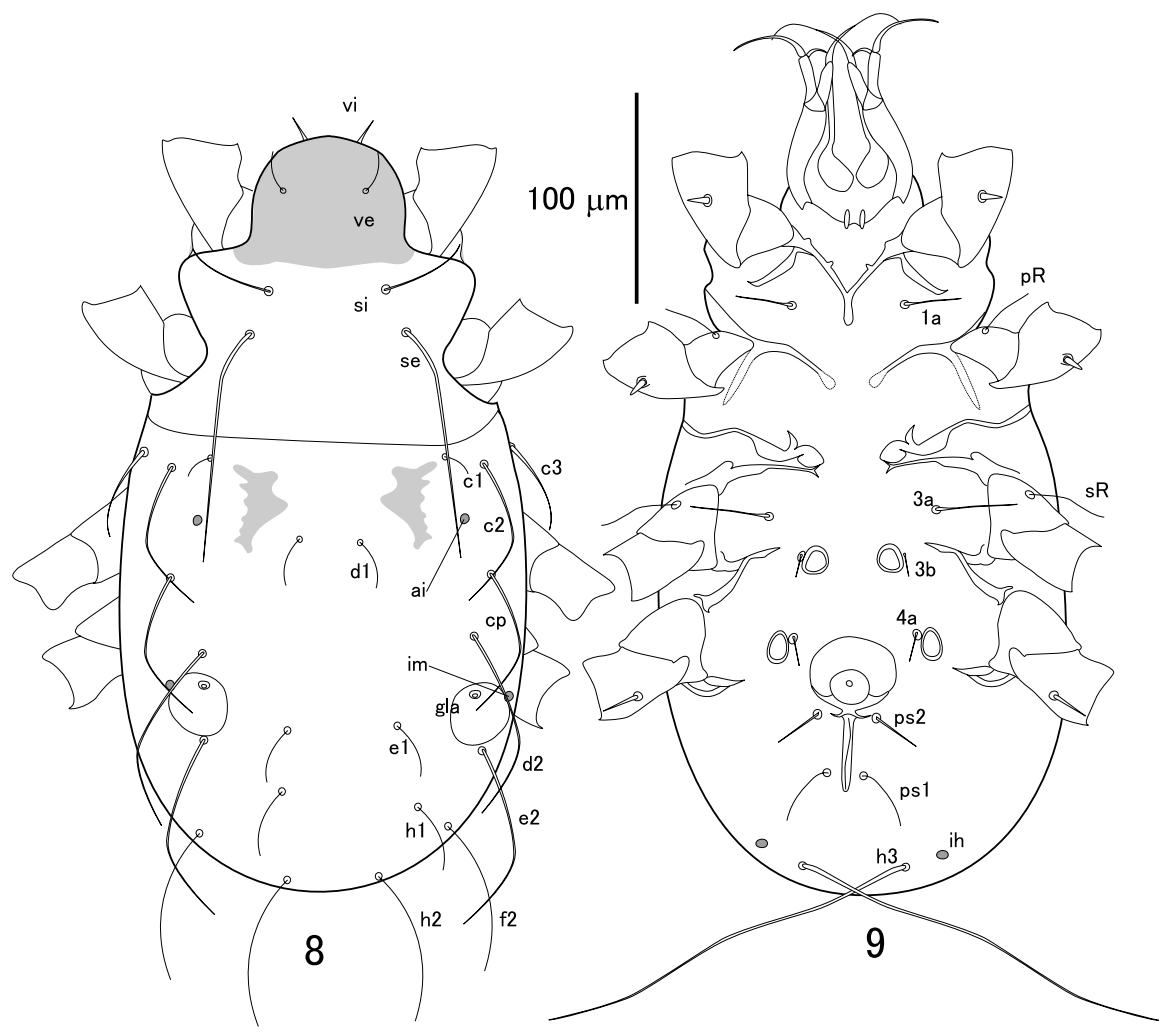

Figs. 8-9. Sarraceniopus nipponensis Tagami, sp. nov., male. 8, dorsum; 9, venter.
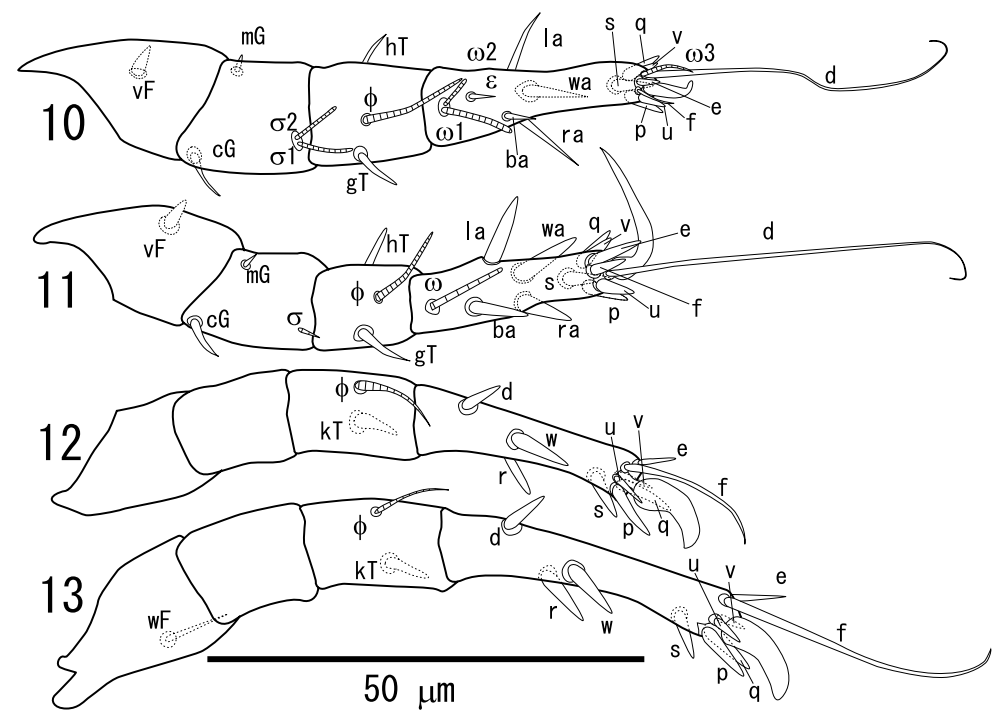

Figs. 10-13. Sarraceniopus nipponensis Tagami, sp. nov., male. 10, leg I; 11, leg II; 12, leg III; 13, leg IV. 


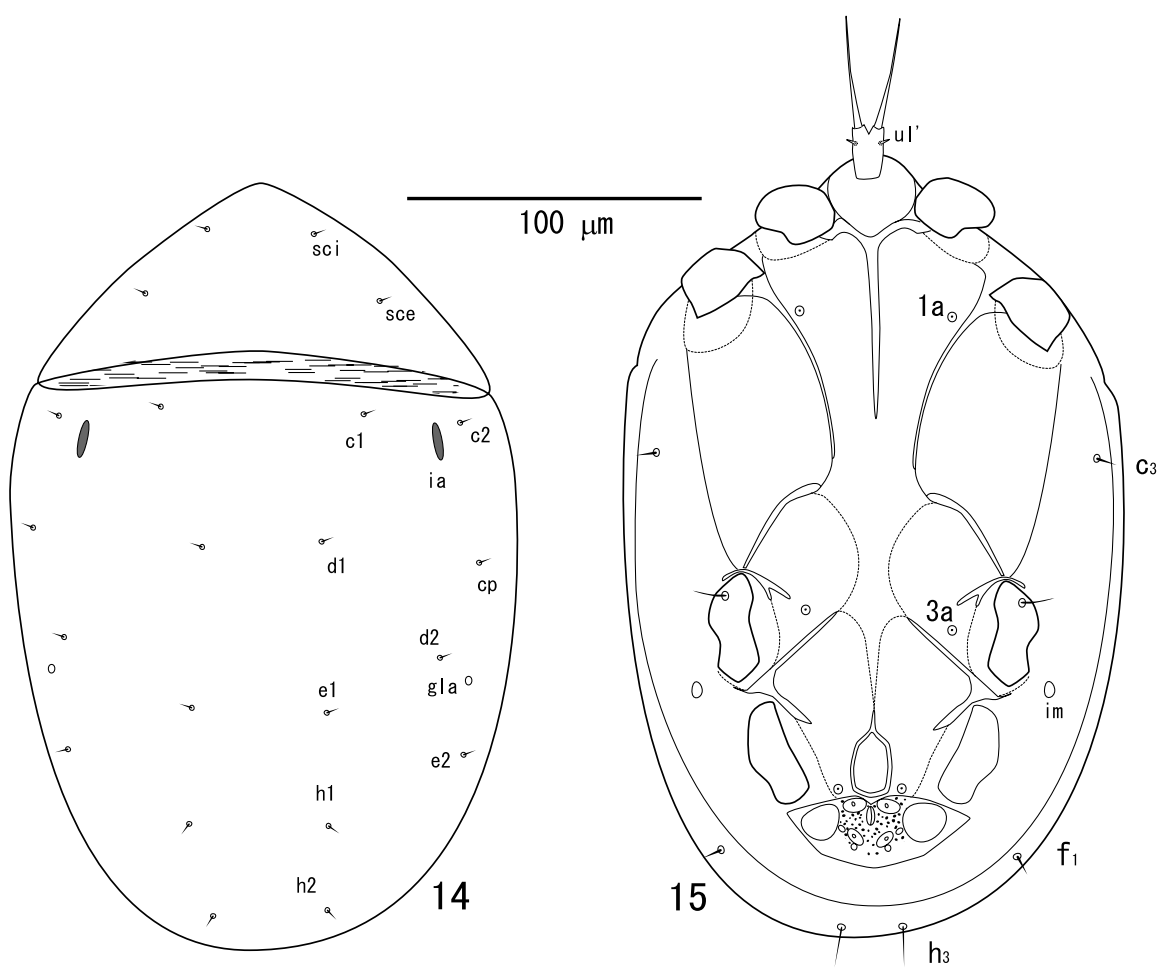

Figs. 14-15. Sarraceniopus nipponensis Tagami, sp. nov., deutonymph. 14, dorsum; 15, venter.

postero-medially and its end free; posterior apodeme II weak; apodemes III extending antero-medially, fused weakly with anterior apodeme II, but not fused medially. Apodemes IV extending forward and its end free. Genital region small and genital setae invisible. Coxal setae $1 a, 3 a$ and $4 a$ distinct but minute. Sucker plate small, wide inverse trapezoidal in shape with striate margin; 17-24 $\mu \mathrm{m}$ long and 52-54 $\mu \mathrm{m}$ wide. Cupule im located on ventral margin at posterior end of trochanter III.

Legs (Figs. 16-19). Total length of distal 4 segments moderate in all legs; tarsal length of legs I and II shorter than length from tibia to femur; total length of leg III subequal with legs I and II; leg IV longer than the other three legs. Chaetotaxy of tibia-genu-femur I-IV as in female; leg setae almost spine-like except $v F$ of leg II, $e, r$ and $s R$ of leg III, and $e, r$ and $w$ of leg IV filiform. Apical tarsal seta $e$ of leg I spoon-shaped; $e$ of leg II leaf-shaped with attenuate apex; $e$ of legs III and IV hair-like and that of leg IV remarkably long. Famulus $\varepsilon$ thick hair-like and shorter than $\omega 1$. Tibial solenidion $\sigma$ of leg I thin and minute triangle. Solenidion $\omega$ of leg II large rod-like and $\sigma$ of leg II like as that of leg I. Claws I-IV large, longer than $14 \mu \mathrm{m}$.

Type series. Holotype: female (Collection No. C25AF01) isolated from a sarraceniaceous pitcher grown in Atagawa, East shore of the Izu Peninsula, Shizuoka Prefecture, southcentral Japan, 17-VI-2000, Satoshi KimuRA leg. Paratypes: 5 females, 6 males and 6 deutonymphs, data same as for holotype. 


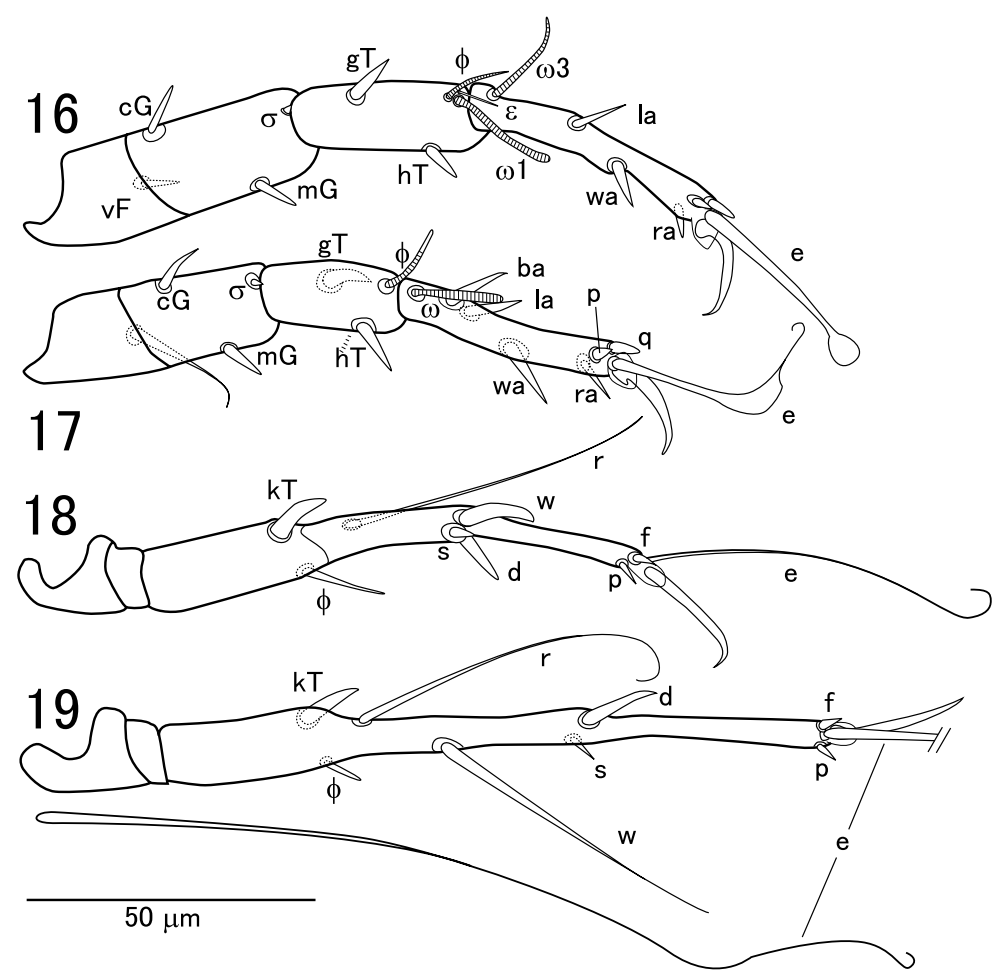

Figs. 16-19. Sarraceniopus nipponensis Tagami, sp. nov., deutonymph. 16, leg I; 17, leg II; 18, leg III; 19, leg IV.

Etymology. The specific epithet is derived from "Nippon", usual Japanese pronunciation for Japan.

Remarks. The present species is closely related to $S$. darlingtoniae. However, it differs from the latter in the following characteristics: hysterosomal setae $c l, d l, e l$ and $h l$ in male and female adults were shorter than $c 2, d 2, e 2$ and $h 2$, respectively, when compared to $S$. darlingtoniae; hysterosomal sclerotized patch in males is smaller than that of $S$. darlingtoniae; hysterosomal patch absent in females while it is present in $S$. darlingtoniae; hysterosoma without punctuations and seta $e$ of leg IV longer than total length of leg IV in deutonymphs, while the seta of $S$. darlingtoniae shorter than tibio-tarsal length of leg IV.

Biology. The plants of the genus Sarracenia from the United States and Canada have been listed (CITES, 1987) and their trade or introduction to Japan was restricted. Sarraceniaceae was introduced to Japan in 1896, but all of the strains vanished during World War II. In 1954, many Sarraceniaceae strains were imported once more from Alabama, Florida, Mississippi and South Carolina (Kusakabe, 1968).

The distribution of pitcher mites has been restricted by the distribution of Sarraceniaceae; S. gibsoni from Sar. purpurea in Quebec, Canada (Nesbitt, 1954) and from Sar. purpurea in Minnesota (Hunter and Hunter, 1964), S. hughesi from Sar. flava and Sar. minor in Georgia and North Carolina (Hunter and Hunter, 1964) and S. darlingtoniae from Darlingtonia cali- 
folnica in northwestern US (Fasing and OConnor, 1984). The present species, S. nipponensis, does not seem to be restricted to host genus or species within the Sarraceniaceae because they inhabit several artificially hybridized species in Japan. Species-specificity of this mite inhabiting plants relative to North American species, and the carrier insect specificity in the original North American and Japanese fauna need to be examined further.

\section{Sarraceniopus hughesi (Hunter \& Hunter, 1964)}

Anoetus hughesi: Hunter \& Hunter, 1964.

Sarraceniopus hughesi: Fashing and OConnor, 1984.

This species was originally collected from Sarracenia minor and Sar. flava pitchers in Georgia and North Carolina, and described. The species can be identified by the following characteristics: longer hysterosomal setae $c l, d l, e l$ and $h l$; a single large hysterosomal sclerotized patch in the female; a large, centrally fused hysterosomal patch in males instead of being paired as in other species when present; and no hysterosomal punctations in deutonymph.

Material examined. Three females, 2 males and 11 deutonymphs isolated from some sarraceniaceous pitchers grown at the Kyoto University Experimental Farm, Kyoto, western Japan, 19-V-2000, Yasumasa KUWAHARA leg.

\section{ACKNOWLEDGEMENTS}

The author would like to thank Dr. Yasumasa KUWAHARA for his kind gift of Sarracenia pitchers from the Kyoto University Experimental Farm. I also thank Mr. Satoshi KIMURA, President of the Atagawa Tropical and Alligator Garden and his staff for the collection of pitchers and personal gifts. Latin advice for the nomenclature was kindly given by Dr. Manabu AKIYAMA, Associate Professor at Tsukuba University.

\section{REFERENCES}

CITES (The Convention on International Trade in Endangered Species of Wild Fauna and Flora), Appendices I, II and III, http://www.cites.org/eng/append/appendices.shtml, 2003.

Fashing, N. J. and B. M. OConnor (1984) Sarraceniopus-A new genus for Histiostomatid mites inhabiting the pitchers of the Sarraceniaceae (Astigmata: Histiostomatidae). International Journal of Acarology, 10: 217-227.

Fashing, N. J. (2002) Nepenthacarus, a new genus of Histiostomatidae (Acari: Astigmata) inhabiting the pitchers of Nepenthes mirabilis (Lour.) Druce in Far North Queensland, Australia. Australian Journal of Entomology, 41: 7-17.

Grandjean, F. (1939) La chaetotaxy des pattes chez les Acaridiae. Bulletin de la Société Zoologique de France, 64: $50-60$.

Griffiths, D. A., W. T. Atyeo, R. A. Norton and C. A. Lynch (1990) The idiosomal chaetotaxy of astigmatid mites. Journal of Zoology (London), 220: 1-32.

Hunter P. E. and C. A. Hunter (1964) A new Anoetus mite from pitcher plants. Proceedings of the Entomological Society of Washington, 66: 39-46.

Kurosa, K. (2002) A new species of Histiostoma (Acari, Histiostomatidae) associated with Lathrobium sp. (Coleoptera, Staphylinidae) in Japan. Special Bulletin of the Japanese Society of Coleopterology, 5: 27-35.

Kusakabe, I. (1968) Historical Records of Japanese Insectivorous Plants Enthusiasm. 1-128, Insectivorous Plant 
Society, Tokyo (in Japanese).

Nesbitt, H. H. J. (1954) A new mite, Zwickia gibsoni n. sp., Fam. Anoetidae, from the pitchers of Sarracenia purpurea L. Canadian Entomologist, 46: 454-468.

Okabe, K. and B. M. OConnor (2001) A method for both mass and individual rearing of fungivorous astigmatid mites (Acari). Experimental and Applied Acarology, 25: 493-504.

Oudemans, A. C. (1915) Anoetus guentheri nov. sp. Zeitschrift für Wissen Insektenbiologie, 11: 242-243.

Oudemans, A. C. (1924) Acarologische Aanteekeningen LXXVI. Entomologische Berichten, 6: 300-310.

Oudemans, A. C. (1932) Opus 550. Tijdschrift voor Entomologie, 75: 207-210.

\section{摘要}

園芸品種のサラセニアから発見された Sarraceniopus 属（ヒゲダニ科, 無気門亜目) のヒゲダ $=2$ 種類

田神一美（筑波大学大学院人間総合科学研究科）

わが国にはサラセニア (北米原産) やネペンテス（東南アジア原産）などの食虫植物の愛 好者が多く，これらの植物が観賞用として一般に流通している。これらの植物では，その葉 が筒状に変形して昆虫を誘引するトラップを形成し, ここに落ちて死んだ昆虫が分解吸収さ れて, 植物の栄養源として利用されているといわれ, ここを生息環境とするヒゲダニ 3 種類 が北米から報告されている. 京都大学の農場, 熱川バナナワニ園, つくば市内の園芸店で栽 培・展示・市販されているサラセニア属（全て交配を加えられた園芸品種）の食虫植物の管 葉を収集し, たくさんの死んだ昆虫が腐敗発酵してスープ状になった内容物から分離したヒ ゲダニを観察した. 得られたヒゲダニ（メス成虫）は, 第 I-III 脚の先端のツメの長さがそれ ぞれの末節長に匹敵するほど長いことから全て Sarraceniopus（サラセニアヒゲダニ）属と同 定した. 更に雌成虫の背板のキチン化の有無と背毛長 $(d 1, e l, h 1)$ の違い, 雄成虫の背板の キチン化の有無や大きさと背毛長 $(d l, e l, h l)$ の違い, ならびに第二若虫の後体部背面の点 刻や第 4 脚の末節の毛 (e) の長さなどの特徵から一種は, Sarraceniopus hughesi Hunter \& Hunter, 1964 と同定し, 未記載種を S. nipponensis（ニッポンサラセニアヒゲダニ）と命名して 記載した. これらのダニは, サラセニア科の食虫植物のみを生息場所とし, この植物がわが 国には分布していないことから，輸入された株に付着していたものが，国内で繁殖維持され ていたものと推定された。 
Appendix. Measurements of Sarraceniopus nipponensis sp. nov. $(\mathrm{n}=6$, range, $\mu \mathrm{m})$

\begin{tabular}{|c|c|c|c|c|c|c|c|}
\hline Character Stage & $\begin{array}{l}\text { Adult } \\
\text { female }\end{array}$ & $\begin{array}{l}\text { Adult } \\
\text { male }\end{array}$ & Deutonymph & Character Stage & $\begin{array}{l}\text { Adult } \\
\text { female }\end{array}$ & $\begin{array}{l}\text { Adult } \\
\text { male }\end{array}$ & Deutonymph \\
\hline Idiosomal L & $432-536$ & $300-392$ & $194-260$ & Dist. ps2-ps2 & $64-76$ & $42-48$ & - \\
\hline Idiosomal W & $264-376$ & $204-224$ & $136-172$ & ps1 & $4-6$ & $18-26$ & - \\
\hline $\mathrm{W} / \mathrm{L}$ & $0.61-0.70$ & $0.48-0.50$ & $0.64-0.66$ & Dist. ps1-ps1 & $40-62$ & $40-50$ & - \\
\hline Leg I length & $206-218$ & $180-194$ & $81-105$ & Sucker L. & absent & absent & $17-24$ \\
\hline RLI leg I & $0.39-0.48$ & $0.48-0.50$ & $0.38-0.42$ & Sucker W. & absent & absent & $52-54$ \\
\hline Leg II length & $184-200$ & $160-176$ & 66-88 & Tarsus I L. & $72-78$ & $60-61$ & $36-46$ \\
\hline RLI leg II & $0.37-0.43$ & $0.43-0.45$ & $0.31-0.34$ & $\omega 1$ & $20-21$ & $19-20$ & $14-23$ \\
\hline Leg III length & $178-194$ & $172-186$ & 68-90 & $\omega 2$ & $12-14$ & $10-14$ & - \\
\hline RLI leg III & $0.36-0.41$ & $0.46-0.48$ & $0.31-0.38$ & $\omega 3$ & $18-22$ & $20-25$ & $15-18$ \\
\hline Leg IV length & $216-248$ & $194-214$ & 84-117 & aa & - & - & $6-9$ \\
\hline RLI leg IV & $0.44-0.55$ & $0.54-0.55$ & $0.41-0.45$ & $\varepsilon$ & $6-11$ & $9-11$ & nd \\
\hline Gnathosoma L. & - & - & $7-12$ & ba & $14-18$ & $11-14$ & nd \\
\hline Gnathosoma W. & - & - & $8-10$ & la & $18-21$ & $14-17$ & nd \\
\hline Palp solenidion & $42-64$ & $31-40$ & $29-34$ & $\mathrm{ra}$ & $26-30$ & $20-27$ & nd \\
\hline ul' & $24-26$ & $16-24$ & $2.4-3.0$ & wa & $16-29$ & $20-24$ & nd \\
\hline $\mathrm{m}$ & $38-52$ & $17-31$ & - & $\mathrm{d}$ & $104-134$ & $88-111$ & nd \\
\hline vi & $11-14$ & $9-12$ & - & Tibia I L. & $30-34$ & $30-34$ & $22-31$ \\
\hline Dist. vi-vi & $30-40$ & $21-31$ & - & $\phi$ & $27-29$ & $23-29$ & $13-17$ \\
\hline ve & $16-22$ & $16-24$ & - & hT & $10-13$ & $10-12$ & nd \\
\hline Dist. ve-ve & $48-58$ & $34-46$ & - & $\mathrm{gT}$ & $20-22$ & $16-19$ & nd \\
\hline sci & $28-40$ & $24-36$ & $4.4-6.7$ & Genu I L. & $40-44$ & $36-40$ & $20-28$ \\
\hline Dist. sci-sci & $78-90$ & $50-58$ & $26-34$ & $\sigma 1$ & $12-18$ & $15-18$ & - \\
\hline sce & $101-132$ & $103-127$ & $4.4-7.0$ & $\sigma 2$ & $13-18$ & $13-16$ & - \\
\hline Dist. sce-sce & $108-116$ & $68-80$ & $60-79$ & $\sigma$ & absent & absent & $0.4-0.4$ \\
\hline $\mathrm{c} 1$ & $16-24$ & $14-21$ & nd & $\mathrm{cG}$ & $15-18$ & $8-11$ & nd \\
\hline $\mathrm{c} 2$ & $85-105$ & $71-98$ & nd & $\mathrm{vF}$ & $8-11$ & $9-11$ & $5-9$ \\
\hline c3 & $46-61$ & $59-62$ & nd & Femur I L. & $60-62$ & $52-60$ & $16-20$ \\
\hline $\mathrm{cp}$ & 94-108 & $82-96$ & nd & $\mathrm{pR}$ & $20-32$ & $26-30$ & nd \\
\hline d1 & $17-22$ & $14-22$ & nd & Tarsus II L. & $68-72$ & $54-60$ & $30-45$ \\
\hline $\mathrm{d} 2$ & $93-110$ & $79-111$ & nd & $\omega$ & $18-22$ & $17-23$ & $10-16$ \\
\hline el & $26-31$ & $26-30$ & nd & ba & $18-22$ & $14-17$ & nd \\
\hline e2 & $83-102$ & $86-111$ & nd & wa & $21-31$ & $27-29$ & nd \\
\hline $\mathrm{f} 2$ & $50-63$ & $62-75$ & nd & la & $21-31$ & $22-23$ & nd \\
\hline h1 & $32-37$ & $31-42$ & nd & ra & $23-26$ & $16-24$ & nd \\
\hline h2 & $58-77$ & 74-91 & nd & $\mathrm{d}$ & $124-149$ & $118-120$ & $31-38$ \\
\hline h3 & $152-176$ & $141-204$ & nd & Tibia II L. & $26-30$ & $25-28$ & $18-24$ \\
\hline la & 28-37 & $32-37$ & nd & $\phi$ & $20-24$ & $19-21$ & $9-12$ \\
\hline Dist. 1a-1a & $72-80$ & $48-54$ & $51-71$ & hT & $12-16$ & $8-14$ & nd \\
\hline $3 a$ & $11-13$ & $31-43$ & nd & $\mathrm{gT}$ & $19-22$ & $17-19$ & nd \\
\hline Dist. $3 \mathrm{a}-3 \mathrm{a}$ & $82-109$ & $72-96$ & $35-40$ & Genu II L. & $40-44$ & $37-40$ & $17-24$ \\
\hline $3 b$ & $32-40$ & $9-11$ & - & $\sigma$ & $15-18$ & $14-15$ & $6-8$ \\
\hline Dist. $3 b-3 b$ & $70-87$ & $30-50$ & - & $\mathrm{cG}$ & $12-17$ & $7-9$ & nd \\
\hline $4 a$ & 14-18 & $10-14$ & nd & $\mathrm{mG}$ & $8-10$ & $14-16$ & nd \\
\hline Dist. $4 \mathrm{a}-4 \mathrm{a}$ & $104-132$ & $56-68$ & $16-18$ & $\mathrm{vF}$ & $9-10$ & $11-14$ & $18-23$ \\
\hline ps3 & 6-8 & absent & - & $\mathrm{pR}$ & $24-30$ & $29-35$ & nd \\
\hline Dist. ps3-ps3 & $40-50$ & absent & - & Femur II L. & $50-56$ & $42-48$ & $16-20$ \\
\hline ps2 & $3-4$ & $13-14$ & - & Tarsus III L. & $76-86$ & $66-70$ & $45-61$ \\
\hline
\end{tabular}




\begin{tabular}{|c|c|c|c|c|c|c|c|}
\hline Character Stage & $\begin{array}{l}\text { Adult } \\
\text { female }\end{array}$ & $\begin{array}{l}\text { Adult } \\
\text { male }\end{array}$ & Deutonymph & Character Stage & $\begin{array}{l}\text { Adult } \\
\text { female }\end{array}$ & $\begin{array}{l}\text { Adult } \\
\text { male }\end{array}$ & Deutonymph \\
\hline d & $20-23$ & $13-14$ & $48-66$ & $\mathrm{r}$ & $22-29$ & $18-22$ & nd \\
\hline $\mathrm{r}$ & $22-25$ & $11-15$ & $13-14$ & $\mathrm{w}$ & $23-27$ & $22-24$ & nd \\
\hline w & $23-26$ & $22-27$ & $6-7$ & Tibia IV L. & $32-40$ & $39-40$ & - \\
\hline Tibia III L. & $32-34$ & $34-38$ & - & $\phi$ & $17-22$ & $16-20$ & $6-8$ \\
\hline$\phi$ & $19-28$ & $22-28$ & $12-16$ & $\mathrm{kT}$ & $18-28$ & $16-19$ & $8-11$ \\
\hline $\mathrm{kT}$ & $19-21$ & $15-22$ & $8-11$ & Genu IV L. & $38-40$ & $36-40$ & $20-30$ \\
\hline Genu III L. & $30-34$ & $32-36$ & $22-30$ & $w F$ & $21-28$ & $23-26$ & nd \\
\hline sR & $28-35$ & $33-41$ & nd & Femur IV L. & $44-48$ & $42-48$ & $16-22 *$ \\
\hline $\mathrm{R}$ & $22-29$ & $18-22$ & nd & Claw I & $40-52$ & $16-18$ & $14-17$ \\
\hline Femur III L. & $36-42$ & $38-44$ & $16-20 *$ & Claw II & $45-65$ & $32-40$ & $14-16$ \\
\hline Tarsus IV L. & $100-120$ & $74-86$ & $63-75$ & Claw III & $48-79$ & $23-24$ & $17-23$ \\
\hline d & $23-28$ & $10-15$ & $86-141$ & Claw IV & $58-83$ & $24-24$ & $20-27$ \\
\hline
\end{tabular}

—: no character. nd: no data. *: Femur length+Trochanter length 